\title{
THE INFLUENCE OF THIRD PARTY FUNDS, CAPITAL ADEQUACY RATIO, NON PERFORMING LOANS TO CREDIT DISTRIBUTION ON THE INDONESIA STOCK EXCHANGE
}

\author{
Desyana Jari Langodai ${ }^{1}$ \\ Novrida Qudsi Lutfillah ${ }^{2}$ \\ Wijaya Putra University Surabaya \\ Desyanajlangoday01@gmail.com \\ vridaoayu@gmail.com
}

\section{A R T I C L E I N F O \\ Article history: \\ Received : 1 February 2019 \\ Revised : 25 February 2019 \\ Accepted : 20 March 2019}

Key words:

Third party funds, capital adequacy

ratio, non-performing loan

DOI:

https://doi.org/10.33508/rima.v2i1.2599

\begin{abstract}
A B S T R A C T
The influence of third party funds, capital adequacy ratio, nonperforming loans to credit distribution on the Indonesia Stock Exchange period 2013-2017. This study aims to examine and analyze the effect of DPK, CAR, NPL on lending. This data was obtained from the official website of the Indonesia Stock Exchange website. The sampling technique uses purposive sampling. Data analysis was performed using statistics with SPSS 21 tools. The research findings show that the calculated t-value results from DPK 15,84 with a significance level 0,000 which means DPK has a positive and significant effect. While CAR and NPL do not have a significant effect on lending because the significance value is greater that $5 \%$. While simultaneously DPK, CAR, NPL affect credit distribution with a significance level of 0,000 .
\end{abstract}

\section{INTRODUCTION}

The current economic growth is inseparable from the role of financial institutions, especially banks. Banking institutions have an essential function in moving the wheels of a country's economy. Based on Article 1 Paragraph 2 of Law Number 10 of 1998 concerning Banking, banks are defined as business entities that collect or collect funds from the public in the form of deposits and distribute them to the people in the form of credit. Good credit growth and development can help improve community welfare. The reason the community is very influential on banks is that the city is the primary source of funds, or more commonly known as third party funds (DPK). If third-party funds increase, the amount of credit given will also increase. The higher the number of deposits collected by banks, the higher the amount of credit that banks can offer to the public (Widyawati, 2015).

Based on regulations from Bank Indonesia No.15 / 12 / PBI / 2013 concerning the minimum capital obligations of commercial banks, that each bank is required to provide a minimum capital of $8 \%$ of the weighted assets according to the risk stated in the capital adequacy ratio (CAR). This aims to increase professionalism and discipline for each bank to process all assets owned to obtain profits for each bank.

One of the things that must be remembered is that banks' main activity in 
obtaining profits is through lending. Still, the biggest problem faced by banks also comes from lending, namely nonperforming loans, the higher the level of NPLs, can lead to credit risk faced by banks is getting higher (Buchory, 2014). The difficulty of banks in channeling credit is due to high NPLs.

\section{Research purposes}

1. To describe the influence of Third Party Funds, Capital Adequacy Ratio, and Non Performing Loans on the lending of PT BPD listed on the Indonesia Stock Exchange in the 2013-2017 period.

2. To find out and analyze the influence of Third Party Funds on PT BPD lending, which is listed on the Indonesia Stock Exchange in the 2013-2017 period.

3. To find out and analyze the effect of Capital Adequacy Ratio on PT BPD lending, which is listed on the Indonesia Stock Exchange in the period 2013-2017.

4. To find out and analyze the influence of Non-Performing Loans on the borrowing of PT BPD listed on the Indonesia Stock Exchange in the 2013-2017 period.

5. To find out and explain whether there is an influence of Third-Party Funds, Capital Adequacy Ratio, and Non-Performing Loans simultaneously on lending for the 2013-2017 period.

Therefore, the reforms carried out in this study are worthy of research by developing independent variables from Pratiwi and Hindasah (2014) and Arianti et al. (2016), which form the basis of this study. The research equation of Arianti et al., (2016) with this study is the independent variable $(x)$ capital adequacy ratio and nonperforming loans and the dependent variable (y) lending, and the difference between the independent variables $(x)$ BOPO and NIM are replaced by the TPF variable taken from Pratiwi and Hindasah research (2014). While Pratiwi and Hindasah's (2014) independent variables (x) of third party funds, capital adequacy ratio, and non-performing loans and the dependent variable (y) lending. And the difference is that the independent variables (x) ROA and NIM are omitted. So it can be concluded that this study took DPK variables from Pratiwi and Hindasah research (2014), capital adequacy ratio, and non-performing loans from Pratiwi and Hindasah research (2014) and Arianti et al., (2016). And removed the ROA and NIM variables from Pratiwi's research and Hindasah (2014) and Arianti et al., (2016) BOPO variables from Arianti et al. (2016), this research was conducted because there were still some problems in the banking world related to bank lending. There were still results that were not following previous studies and to explore further and develop existing studies.

From the description above, the authors are interested in reexamining existing research with the title "Analysis of the Effects of Third Party Funds, Capital Adequacy Ratio, and Non-Performing Loans on Credit Distribution at PT BPD listed on the Indonesia Stock Exchange 2013-2017".

\section{LITERATURE REVIEW}

Bank

A bank is a business entity that collects funds from the public in the form of deposits and channels them back to the community in the form of credit and or other ways to improve the lives of many people (Kasmir, 2014: 14). While the understanding of the bank according to PSAK No.31 in Government Accounting Standards explains that the bank is an institution that acts as a financial intermediary (financial intermediary) between parties who have excess funds (surplus units) with those who need funds (deficit funds), as well as an institution that functions to expedite payment traffic. From this statement, it can be concluded that the 
bank is one of the financial institutions whose job is to collect funds from the public and channel it back to the community and has a vital role in the economic growth of a country.

In general, the function of a bank is to collect funds from the public and channel it back to the community for various purposes. The bank can function as follows:

1. Agent of trust

institutions whose foundation is trust. The primary basis for banking activities is trust, both in raising funds and in channeling funds. If the community is based on trust, they will want to save their funds in the bank.

2. Agent of development

Agent of development is institutions that mobilize funds for economic growthcommunity economic activities in the real sector and the monetary sector. The two industries cannot be separated; they always interact and influence each other. The financial sector does not perform well if the real area cannot perform well. The activities carried out by the bank enable the public to carry out investment activities, distribution activities, and the consumption of goods and services. It can be seen that investmentdistribution-consumption activities cannot be free from the use of money. This smooth investment-distribution-consumption activity is none other than economic development activities.

3. Agent of services

The agent of services is institutions that raise funds for economic development. In addition to conducting fundraising and distribution activities, banks also offer other banking services to the public. The services provided by this bank are closely related to the general economic activities of the community. These services can include functions for safekeeping valuable goods, sending money, and settling bills.

Types of Banks
According to cashmere (2014), the type of banking can be seen in various aspects:

1. In terms of function,

a. commercial banks

based on Act Number 10 of 1998 concerning banking, what is meant by Commercial Banks are institutions that carry out normal business activities or based on sharia principles in their activities of providing payment traffic services.

b. rural banks

In Banking Law Number 10 of 1998 concerning banking, a Bank is an institution that carries on business activities conventionally and based on sharia principles in which its actions do not provide payment traffic services.

2. In terms of ownership

in Law No.10 of 1998 According to bank ownership, banks can be divided into five categories, namely:

a. State-Owned Bank

b. Regional Government Bank

c. National Private Bank

d. Foreign Private Bank

e. Mixed Commercial Bank (joint venture bank)

\section{Hypothesis}

According to Kasmir (2014) that third-party funds are funds from the wider community, which are the most critical source of funds for a bank's operational activities and are a measure of the success of a bank if it can finance its operations from this source of funds. Listed below are several types of third party funds according to Banking Law Number 10 of 1998 dated November 10:

1. Demand Deposit (Demond Deposit)

Deposits can be withdrawn at any time by using checks, crossed checks, other means of payment orders by transferring books.

2. Savings Savings

Deposits that can be removed can only be carried out according to certain agreed conditions, but cannot be withdrawn by 
check, giro and or other equivalent instruments.

\section{Deposits}

Deposits can only be removed at a particular time based on the agreement between the customer and the bank to save.

Capital adequacy ratio (CAR) is the ratio of bank performance to measure the adequacy of capital owned by banks to support assets that contain or generate risk. According to Ismaulandy (2014), that wealth consists of core capital and supplementary capital. Core capital is divided into two, namely, paid-up capital and additional capital reserves comprising other factors (profit a few years ago after tax was calculated) and a deduction factor (losses a few years ago). With capital that can maintain public trust in the bank concerned, so that the community believes in saving funds to the bank, the funds collected are then channeled by the bank again to the public through credit. Bank Capital is the amount of capital that comes from banks consisting of additional capital and core capital. While risk-weighted assets are calculations that cover assets contained in statements of financial position and administrative assets as reflected in contingency liabilities that are prepared by banks for third parties. To find out the amount of RWA, it takes a calculation from the results of the simple multiplication of assets with the risk weight of each asset related to the magnitude of the risk level of the insured in each part of the asset itself, or the nature of the collateral or the risk weight of the loan.

Based on the description above and previous research, a hypothesis (H2) can be made: Capital adequacy ratio has a positive and significant effect on lending.

Each bank will find the credit that carries a higher risk than when approving credit applications in its credit portfolio. Occasionally banks also come across loans/loans, which may take far more significant risks than those who are usually still willing to face. That could have happened due to weakness in considering the credit concerned because of the deteriorating economic situation. Caused because of misrepresentation by the customer or mismanagement in the company, or as a result of something that cannot be prevented by humans, such as a customer dies. These ordinary loans are called non-performing loans (NPLs). According to Latumerissa (2014: 164) that NPL is one indicator of the soundness of commercial banks. The high NPL refers to the inability of commercial banks in the process of the appraisal to the disbursement of credit to debtors. On the other hand, the NPL also causes a high cost of capital, which is reflected in operational costs for the Commercial Bank concerned. Net profit from the bank will affect if the cost of capital is high adrift.

Based on the description above and previous research, a hypothesis (H3): Nonperforming loans (NPL) can have a negative and significant effect on lending.

\section{METHODOLOGY}

Population, Samples, Sampling

The study population is all banking companies listed on the Stock Exchange in the 2013-2017 period as many as 31 companies. The sampling method in this study uses a purposive sampling method, which is sample selection based on specific criteria.

a. Banking companies listed successively on the Indonesia Stock Exchange in 2013-2017. b. Companies that can be accessed in full annual report or audit financial statements in a row on 2013-2017 in the Indonesian Stock Exchange.

The sample selection criteria can be seen in table 1.

Table 1. Sample Selection Criteria

\begin{tabular}{|l|l|l|}
\hline No & Criteria Sample & Total \\
\hline
\end{tabular}




\begin{tabular}{|l|l|l|}
\hline & & company \\
\hline 1 & $\begin{array}{l}\text { Banking companies listed } \\
\text { successively on the Indonesia } \\
\text { Stock Exchange in 2013-2017 }\end{array}$ & 31 \\
\hline 2 & $\begin{array}{l}\text { Companies that can not be } \\
\text { accessed in full by annual } \\
\text { report or audit financial } \\
\text { statements in a row on the } \\
\text { Indonesia Stock Exchange in } \\
\text { 2013-2017 }\end{array}$ & 23 \\
\hline 3 & $\begin{array}{l}\text { Companies that can be } \\
\text { accessed in full by annual } \\
\text { report or audit financial } \\
\text { statements in a row on the } \\
\text { 2013-2017 Indonesian Stock } \\
\text { Exchange }\end{array}$ & 8 \\
\hline & \multicolumn{2}{|c|}{} \\
\hline
\end{tabular}

\section{Data Types and Sources}

Data collection techniques used in this study using documentation and literature, the data were taken in this study are secondary data: data that has been processed and collected by institutions or data collection agencies and published. In this study, the data used is the annual report of banking companies listed on the Indonesia Stock Exchange in 2013-2017.
Data collection in this study was obtained from the official website of the IDX (www.idx.co.id).

\section{Technical and Data Analysis}

This research uses descriptive analysis techniques, and classic assumption test, the traditional assumption test consists of a normality test, multicollinearity test, heteroscedasticity test, and autocorrelation test.

Hypothesis testing itself uses multiple linear regression analysis, the hypothesis in this study using the t-test and $f$ test to determine the effect of each variable. The regression equation in this study:

$\mathrm{Y}=\mathrm{a}+\mathrm{b} 1 \mathrm{X} 1+\mathrm{b} 2 \mathrm{X} 2+\mathrm{b} 3 \mathrm{X} 3+\mathrm{ei}$

Information:

$$
\begin{array}{ll}
\mathrm{Y} & =\text { Beta } \\
\mathrm{A} & =\text { constant } \\
\mathrm{b} 1, \mathrm{~b} 2, \mathrm{~b} 3, \mathrm{~b} 4 & =\text { Coefficient of Determination } \\
\mathrm{X} 1 & =\text { Third Party Funds } \\
\mathrm{X} 2 & =\text { Capital Adequacy Ratio } \\
\mathrm{X} 3 & =\text { Non-Performing Loan } \\
\mathrm{E} & =\text { Std.error }
\end{array}
$$

\section{RESULT}

Descriptive Statistics Test

Table 2. Descriptive Statistics Test Results

\begin{tabular}{llllll}
\hline & N & Minimum & Maximum & Mean & Std. Deviation \\
\hline DPK & 40 & 7,88 & 11,30 & 9,460 &, 925 \\
CAR & 40 & 2,62 & 3,40 & 2,947 &, 217 \\
NPL & 40 & $-4,61$ & 2,07 &, 540 & 1,105 \\
Penyaluran Kredit & 40 & 7,96 & 11,17 & 9,417 &, 835 \\
Valid N (listwise) & 40 & & & & \\
\hline
\end{tabular}

Descriptive statistical analysis is used to describe the minimum, maximum, average (mean), standard deviation from each research variable. The table below shows that the valid data is 40 firm-years during the study period in 2013-2017-the explanation of each variable. From table 1 below, it can also be seen that the mean 
value of credit distribution is 9,417 , with a standard deviation of 0.835 . the average cost (mean), which is higher than the value of the standard deviation (Standard Deviation), shows that the credit distribution data is well distributed.

The independent variable obtained from third party funds (DPK) has the lowest 7.88 , the highest amount of 11.30, and an average DPK of 9.460. Whereas the standard deviation for DPK is 0.925 . The high mean value compared to the standard deviation of TPF data shows that the difference in TPF data can be useful.

Capital Adequacy Ratio (CAR) has the lowest value of $2.62 \%$ and the highest value of $3.40 \%$. While the average CAR value is $2.947 \%$ with a standard deviation value of $0.217 \%$, this shows that the data used in the CAR variable has a small distribution because the standard deviation is lower than the mean (mean), so the difference of data on this CAR variable can be said to be good.

Non-Performing Loans (NPLs) have a minimum value of $-4.61 \%$ and a maximum of $2.07 \%$. While the mean NPL of $0.540 \%$ with a standard deviation of 1.105 . This shows that the data used in the NPL variable has an extensive distribution because the standard deviation is higher than the average value so that the difference of data on this NPL variable can be said to be unfavorable.

\section{Normality Test}

\section{Figure 1. Normal P-P Plot}

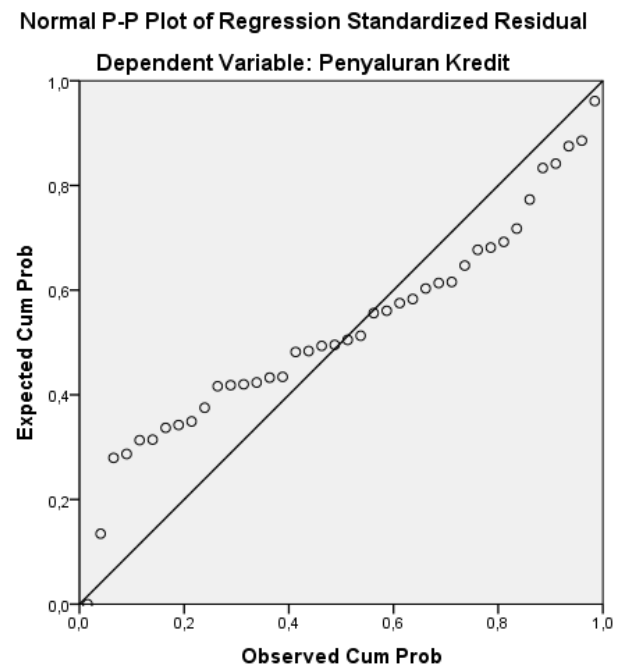

The normality test aims to obtain unstandardized residual values. From the test results above, it can be seen that the points spread around a line following a line and following a diagonal line make a regular wave pattern. Then it can be concluded that the residual value for this regression model is standard and meets the normality assumption where the data distribution is normal

\section{Multicollinearity Test}

Table 3 Multicollinearity Test 


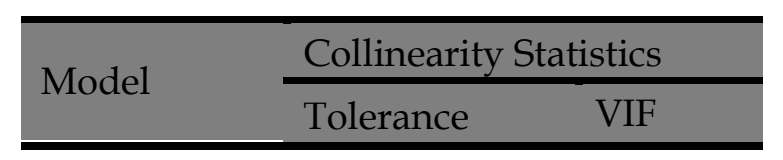

\section{(Constant)}

DPK $\quad 1,869$

CAR $\quad 1,013$
this study intends to test whether the (CAR) and Non Performing Loans (NPL) regression model found a correlation because the tolerance value and VIF each between independent variables. Based on indicate the tolerance value of all table 2 above. Then it can be concluded that independent variables> 0.10 and VIF value there is no correlation between the $<10$. independent variables namely Third Party

\section{$\underline{\text { Heteroscedasticity Test }}$}

Table 4. Heteroscedasticity Test Results

\begin{tabular}{|c|c|c|c|c|c|}
\hline \multirow[t]{2}{*}{ Model } & \multicolumn{3}{|c|}{ Unstandardized Coefficients Standardized Coefficients $]$} & $\mathrm{T}$ & \multirow[t]{2}{*}{ Sig. } \\
\hline & B & Std. Error & Beta & & \\
\hline (Constant) &,- 225 & ,158 & & $-1,424$ & 163 \\
\hline DPK & ,047 & 024 & ,352 & 1,951 & 059 \\
\hline${ }^{1}$ CAR & ,057 & ,092 & 099 & 617 & ,541 \\
\hline NPL & ,000 & 020 &,- 002 &,- 011 & ,991 \\
\hline
\end{tabular}

The Heteroskedasticity Test conducted in this study intends to test whether there is a variance between the residuals in the regression model. Based on table 3 below, it can be concluded that there are no heteroscedasticity symptoms because

\section{$\underline{\text { Autocorrelation Test }}$}

Model Summaryb

$$
\text { Table } 5 \text { Autocorrelation Test }
$$

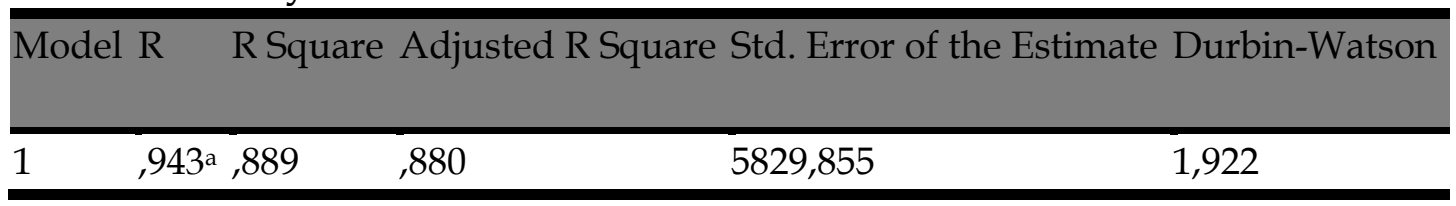

the Glejser test results show the significance of DPK, CAR, and NPL is above 0.05. Hence, it is feasible to be used to predict fixed variables. 
An autocorrelation test used to determine whether there are autocorrelation symptoms from each independent variable. Based on table 4 below, the Durbin-Watson value is 1,922 . Furthermore, it is compared with the table value of $5 \%$ significance level, sample size $40(\mathrm{n}=40)$, and independent variable $3(\mathrm{k}=3)$. So from the DurbinWatson table, the lower limit value (dl) is
1.3384, and the upper limit (du) is 1.6589. Then the calculation with $\mathrm{du}<\mathrm{dw}<4-\mathrm{du}$ can be obtained results of $1.6589<1,922<4$ 1,6589 . So the calculation is obtained 1.6589 $<1.922<4-2.3411$ so that the data is not rejected so that no autocorrelation occurs.

Multiple Linear Regression Test

Table 6. Regression Analysis Test Results

\begin{tabular}{|c|c|c|c|c|c|}
\hline \multicolumn{6}{|l|}{ Coefficients $^{a}$} \\
\hline \multirow[t]{2}{*}{ Model } & \multicolumn{3}{|c|}{ Unstandardized Coefficients Standardized Coefficients } & \multirow{2}{*}{\multicolumn{2}{|c|}{ Sig. }} \\
\hline & $\bar{B}$ & Std. Error & Beta & & \\
\hline (Constant) & 5161,152 & 4542,768 & & 1,136 & ,263 \\
\hline DPK & ,758 & ,048 & ,944 & 15,854 & , 000 \\
\hline 1 CAR & $-120,239$ & 210,807 &,- 032 &,- 570 &, 572 \\
\hline NPL & $-149,536$ & 571,099 &,- 016 &,- 262 & 795 \\
\hline
\end{tabular}

This analysis is used to determine the effect of each independent variable on fixed variables. To interpret the independent variable (independent) can use Unstandardized Coefficients because the data used are pure ratio scale, and have an absolute zero value. As a calculation used multiple linear regression equation models, namely: $Y=5161,152+0,758 X 1+-120,239 X 2+-$ $149,536 \times 3+\mathrm{e}$

\section{$\underline{\text { Determination Test }}$}

Table 7 Determination Test

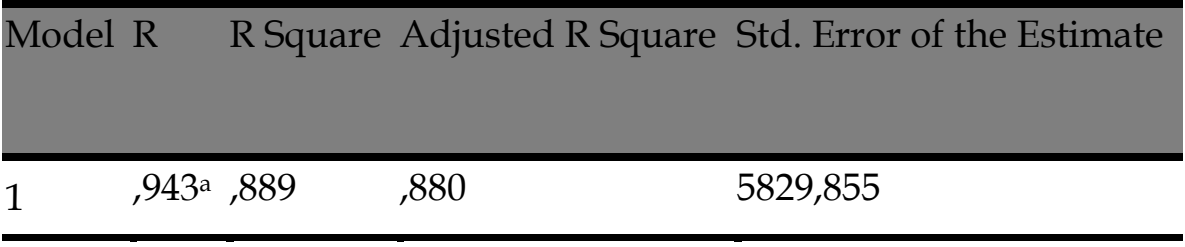

a. Predictors: (Constant), NPL, CAR, DPK

b. Dependent Variable: Credit Distribution 
The determination test is used to find the contribution of independent variables to the dependent variable. From the above data, it can be seen that the adjusted R2 value is 0.889 . This shows that as much as $88.9 \%$ of credit distribution is influenced by variations of the three independent variables used, namely DPK, CAR, and NPL. In contrast, the rest is influenced by other causes outside this research model.

Hypothesis test

$\underline{\text { T-test }}$

Table 8 Partial Test

\begin{tabular}{|c|c|c|c|c|c|}
\hline \multirow[t]{2}{*}{ Model } & \multicolumn{3}{|c|}{ Unstandardized Coefficients Standardized Coefficients } & $\mathrm{T}$ & \multirow[t]{2}{*}{ Sig. } \\
\hline & B & Std. Error & Beta & & \\
\hline (Constant) & 5161,152 & 4542,768 & & 1,136 & 263 \\
\hline DPK & ,758 & , 048 & ,944 & 15,854 & , 000 \\
\hline${ }^{1}$ CAR & $-120,239$ & 210,807 &,- 032 &,- 570 &, 572 \\
\hline NPL & $-149,536$ & 571,099 &,- 016 &,- 262 & ,795 \\
\hline
\end{tabular}

a. Dependent Variable: Penyaluran Kredit

a. Dependent Variable: Credit Distribution This partial test aims to find out how much influence each independent variable has on a fixed variable, how far the power of one variable or explanatory variable individually can explain the fixed variable. The hypothesis in this study is that the DPK, CAR, and NPL factors partially have a significant effect on lending to BPD on the Indonesia Stock Exchange.

In the table you can see the results of the $t$ test:

Research variable third party funds (DPK) as an independent variable. That the coefficient of t-test results from third party funds (DPK) shows a significance level of $0,000<0.05$, for the value of $t$ count, 15.854> $t$ table 2.028 because the cost of $t$ is higher than $\mathrm{t}$ table, then $\mathrm{H} 0$ is rejected, and $\mathrm{H} 1$ is accepted. Then it can be concluded that third party funds (DPK) affect lending in a positive and significant way. The TPF variable has a positive regression coefficient, which is 0.758 . A positive coefficient value indicates that DPK on loan has a positive effect. This illustrates that if there is an increase in deposits by as much as 1 percent, it will cause an increase in lending by 0.758 percent. These results reinforce the results of previous studies conducted by Pratiwi and Hindasah (2014), Selvie et all (2017), and Putra and Rustariyuni (2015) that third-party funds have a positive and significant effect on lending. The high amount of third party funds shows that the funds collected by banks from the public are also top. This can be caused by public trust in banks that can manage federal funds appropriately. An increase in public confidence in excellent banking performance and the desire to get 
more profit will increase the demand for public credit (Amalia, 2018).

CAR research variables as independent variables indicate a significance level of $0.572>0.05$. For the value of $t$ count -0.570 $<\mathrm{t}$ table 2.028. Because $\mathrm{t}$ arithmetic is smaller than the $\mathrm{t}$ table, then $\mathrm{H} 0$ is accepted, and $\mathrm{H} 1$ is rejected. Then it can be concluded that CAR does not affect lending. CAR variable has a negative regression coefficient that is equal to -120.239. The negative coefficient value shows that CAR has a negative effect on loan. This illustrates that if there is an increase in the amount of CAR as much as one percent, it will cause the cost of the credit will also decrease by 120.239 percent. This is supported by research conducted by Putra and Wirathi (2014) and Pratiwi and Hindasah (2014), stating that the level of capital adequacy does not affect lending. But contrary to research conducted by Arianti et al. (2016) that CAR has a positive effect on credit. The differences in this study might be due to differences in the sample used. The mean CAR value is $19.50 \%$, this figure is far from the regulatory limit that must be fulfilled, which is $8 \%$. The great CAR indicates that financial resources (capital) are sufficient to reduce the credit risk faced (Iwanicz and Witkowski, 2015). Banking because it has passed the minimum capital, it encourages banks to optimize resources for various activities to profit (Armana, 2011).

The NPL research variable as an independent variable shows a significance level of $0.795>0.05$. For $t$ arithmetic -0.262 $<\mathrm{t}$ table 2.028, then H0 is accepted, and H1 is rejected. Then it can be concluded that the NPL does not affect lending. The NPL variable has a negative regression coefficient, which is $-149,536$. This negative coefficient value shows that the effect of NPL on the amount of credit distribution is negative. This illustrates that if there is an increase in the cost of NPLs by one percent, it will reduce the lending value by 149.536 percent. This result contradicts research conducted by Putra and Wirathi (2014), Pratiwi and Hindasah (2014), and Arianti et all (2016) that NPL affects lending. The condition of NPLs is also a reasonable risk for banking business, and the high NPL has to do with worsening global economic conditions, causing debtors to have difficulty paying installments so that NPLs are not used as a banking reference lending (Supiatno et al. 2014). This influential NPL can be caused by a high CAR value. This step is expected to overcome credit risk or high NPL (Sania, 2016). The NPL does not affect because the average NPL is still in a small range of values.

\section{$\underline{F \text { test }}$}

Table 9. Simultaneous Test Results

ANOVAa

\begin{tabular}{llllll}
\hline Model & Sum of Squares & Df & Mean Square & F & Sig. \\
\hline \multicolumn{1}{c}{ Regression } & 9802197911 & 3 & 3267399304 & 96,136 &, $000^{\mathrm{b}}$ \\
1 Residual & 1223539457 & 36 & 33987207 & & \\
Total & 11025737368 & 39 & & & \\
\hline
\end{tabular}

a. Dependent Variable: Penyaluran Kredit

b. Predictors: (Constant), NPL, CAR, DPK

Testing The hypothesis of the F-test aims to calculate whether together the independent variables that affect the fixed variable. This study assumes that the DPK, CAR, and NPL factors simultaneously have a significant 
impact on lending to BPD on the Indonesia Stock Exchange.

Based on the table above it is known that the significance value for the effect of $X 1, X 2$ and $\mathrm{X} 3$ simultaneously on $\mathrm{Y}$ is $0,000<0.05$ and the calculated $F$ value is 96.136> F table is 2.86 , so it can be concluded that $\mathrm{X} 1, \mathrm{X} 2$, X3 simultaneously influence $\mathrm{Y}$.

\section{REFERENCES}

Amalia. 2018. Analisis Pengaruh Variabel Internal Bank dan Kebijaknan Moneter terhadap Penyaluran Kredit Perbankan pada BUSN Devisa dan BUSN Non Devisa Go Public periode Tahun 2012-2016. Jurnal Ilmu Manajemen Volume 6 Nomor 4 Jurusan Manajemen Fakultas Ilmu Ekonomi Universitas Negeri Surabaya.

Armana. Billy. 2010. Analisis Faktor-Faktor yang Mempengaruhi Kebijakan Penyaluran Kredit Perbankan. Tesis, Pascasarjana Universitas Diponegoro. Semarang.

Bank Indonesia, 1998. Undang-Undang Nomor 10 Tahun 1998 tentang Perbankan, (Direktur Direktorat Hukum Bank Indonesia, 65). https://doi.org/10.1007/s13398-014$\underline{0173-7.2}$

Bank Indonesia. 2013. Peraturan Bank Indonesia No. 15/12/PBI/2013. Jakarta.

Buchory, Herry Achmad. 2014. Analysis Of The Effect Of Capital, Credit Risk And Profitability To Implementation Banking Intermediation Function (Study On Regional Development Bank All Over Indonesia Year 2012). International Journal of Business, Economic and Law, Vol. 4, Issue 1 (June).
Ismaulandy, Willdan, 2014. Analisis Variabel DPK, CAR, NPL, LDR, ROA, GWM, dan Inflasi terhadap Penyaluran Kredit Investasi pada Bank Umum (Periode 2005-2013), Jurnal Ilmiah Ilmu Ekonomi UB.

Iwanicz-D. Malgorzata. Witkowski. Bartosz. 2015. Credit Growth in Central, Eastern and South-eastern Europe : The Case of Foreign Bank Subsidiaries. International Review of Financial Analysis 919. Elsevier.

Kasmir. 2014. Bank dan Lembaga Keuangan Lainnya. Edisi Revisi, Cetakan keempatbelas, PT. RajaGrafindo Persada, Jakarta.

Kasmir. 2016. Analisis Laporan Keuangan. Jakarta : PT. Raja Grafindo Persada.

Latumaerissa. 2014. Bank dan Lembaga Keuangan Lain. Jakarta : Salemba Empat.

Pratiwi. Hindansah. 2014. Pengaruh DPK, CAR, ROA, NIM dan NPL Terhadap penyaluran kredit Bank Umum di Indonesia. Jurnal Manajemen dan Bisnis. Vol 5 No 2.

Putra. Rustariyuni. 2015. Pengaruh DPK, BI Rate dan NPL Terhadap Penyaluran Kredit Modal Kerja pada BPR di Provinsi Bali Tahun 2009-2014. EJurnal EP UNUD, 4 (5): 451-464.

Sania. Zulcha Mintachus. 2016. Pengaruh DPK, NPL dan CAR terhadap Jumlah Penyaluran Kredit Perbankan Persero. Jurnal Ilmu dan Riset Manajemen, 5(1), 1-15. ISSN : 2461-0593.

Selvie. Arfan. Abdullah. 2017. Pengaruh Dana Pihak Ketiga, Suku Bunga Kredit dan Modal Bank terhadap 
Bank Perkreditan Rakyat Konvensial di Indonesia. Jurnal Megister Akuntansi. Vol. 6 No 2.

Supiatno, et all. 2014. Penagruh NPL, CAR dan Tingkat Suku Bunga terhadap Penyaluran Kredit Perusahaan Perbankan yang Terdaftar di Bursa Efek Indonesiapada Tahun 2009-2011. Online Mahasiswa Bidang Ilmu Ekonomi, 1(1), 1-15.

Widyawati, Sasanti dan Wahyudi, S.T. 2015. Determinasi Pertumbuhan Kredit Modal Kerja Perbankan di Indonesia. Jurnal Ilmiah. Universitas Brawijaya: Malang. 